\title{
CALCULATION OF GAMMA-RAY ATTENUATION PARAMETERS FOR ALUMINIUM, IRON, ZIRCONIUM, AND TUNGSTEN
}

\author{
Hiwa Mohammad Qadr* \\ Department of Physics, College of Science, University of Raparin, Sulaimanyah, Iraqi Kurdistan, Iraq
}

(Received October 15, 2019)

\begin{abstract}
The purpose of this study was to determine the linear attenuation coefficient, the mass attenuation coefficient, Half Value Layer. Tenth Value Layer and Mean Free Path for four different shielding materials such as aluminium, iron, zirconium and tungsten. By using the gamma-radiation energies emitted from ${ }^{152} \mathrm{Eu},{ }^{22} \mathrm{Na},{ }^{137} \mathrm{Cs}$, and ${ }^{60} \mathrm{Co}$ radioactive sources. For this purpose, the attenuation measurements were performed using $N a I(T I)$ detector. Calculated values of all parameters of the all shielding materials were compared with each other. The results of all presented parameters show that, tungsten has the best radiation shielding compared to other shielding materials. Then, the obtained parameters were compared with the theoretical values.
\end{abstract}

PACS: 03.65.Pm, 03.65.Ge, 61.80.Mk

\section{INTRODUCTION}

Recently, the development of nuclear technology have been climbing rapidly because the number of people in the world has increased dramatically. Approximately $16 \%$ of the world's supply of electrical power has come from nuclear power [1]. This percentage is noticeably expected to rise day by day. Nevertheless, on the disadvantageous side, if nuclear power generation is exposed, an accident could affect the health and safety of the public living in vicinity of it. Nowadays, the use of gamma rays in medical diagnostics [2, $3]$, nuclear diagnostics, surgery, industry, agriculture $[4,5]$ and research are increasing rapidly $[6]$. Therefore, the knowledge of gamma-ray interaction is gaining more importance from perspective of shielding against their effect on biological matter. Thus, the linear attenuation coefficient, the mass attenuation coefficient, Half Value Layer, Tenth Value Layer and Mean Free Path are an important parameters that must be known to design and choose a shielding material. Gamma-ray interaction with matter relies on the extent of absorption or scattering, incident photon energy, type of the material and also on the geometrical conditions [7]. There are several type of the most important interaction mechanisms of gamma ray with matter. These interactions are photoelectric effect, Compton scattering and pair production. These mechanisms of interaction cause the attenuation of the incident of gamma-ray [8]. During recent years, there are a large number of experimental, theoretical and simulation studies have been applied on the absorbed dose and radiation shielding parameters in various way, have been widely studies by many re- search groups [9-16]. The objective of this study is to determine the values of above parameters. Then, the obtained the values of parameters were compared with theoretical values of shielding materials at different energy.

\section{MATERIALS AND METHODS}

\section{Experimental details}

Fig.1 shows the schematic view of the experimental setup. The used radiation sources comprised ${ }^{152} \mathrm{Eu}$, ${ }^{22} \mathrm{Na},{ }^{137} \mathrm{Cs}$, and ${ }^{60} \mathrm{Co}$ radioactive elements with different energies of 244.67, 344.30, and $788.90 \mathrm{keV}$ for ${ }^{152} \mathrm{Eu}, 511.00 \mathrm{keV}$ for ${ }^{22} \mathrm{Na}, 661.00 \mathrm{keV}$ for ${ }^{137} \mathrm{Cs}$, 1171.00 and 133.00 for ${ }^{60} \mathrm{Co}$. The materials used as the shield are aluminuim, iron, zirconium and tungsten. The detector in this work is sodium iodide NaI(TI) scintillation detector with a multi Channel Analyzer (MCA). The gamma-ray spectra are analyzed by the maestro program. The shielding materials was placed between the detector and the radioactive source. The distance between the radioactive source and the shielding material was $5 \mathrm{~cm}$ and the distance between the detector and the radioactive source was $9 \mathrm{~cm}$. Data acquisition time was chosen as 5 min for each shielding materials. The first reading was recorded after passing gamma-rays through the shielding materials. At the beginning, an initial measurement with no shielding material in place was taken. Then, this step was repeated for the different shielding materials. All point sources have been repeated five times for each shielding material.

\footnotetext{
${ }^{*}$ Corresponding author E-mail address: hiwa.physics@uor.edu.krd
} 


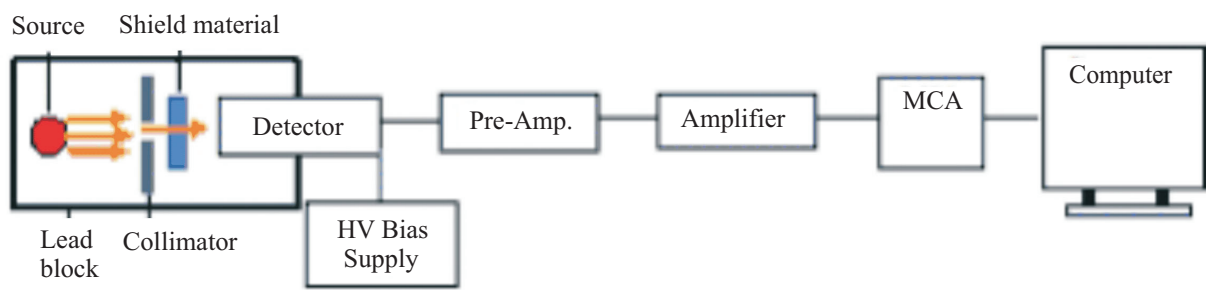

Fig.1. Diagram of the experimental setup

\section{Theoretical calculations}

In this work, I summaries theoretical background relations that were utilized for the determination linear attenuation coefficient $\mu$, mass attenuation coefficient $\mu_{m}$, Half Value Layer HVL, Tenth Value Layer TVL and Mean Free Path MFP. According to LambertBeer's law, gamma rays are attenuated when the fractional radiation intensity passing through an absorber as compared to the source intensity [17]. The following equation describes the transmitted beam at any thickness of the absorber.

$$
I=I_{0} e^{-\mu x},
$$

where $I_{0}$ and $I$ are the un-attenuated and attenuated gamma ray beam intensities, $\mu\left(\mathrm{cm}^{-1}\right)$ is the linear attenuation coefficient of the absorber and $x(\mathrm{~cm})$ is the thickness of the material. The linear attenuation coefficient is related to many factors such as the shielding material, the incident gamma-ray energy and the density of the material [18]. Rearrange equation (1) for the value of the linear attenuation coefficient is calculated by the following equation:

$$
\mu=\frac{\ln \left(I / I_{0}\right)}{x} .
$$

The mass attenuation coefficient $\mu_{m}\left(\mathrm{~cm}^{2} / \mathrm{g}\right)$ can be defined as a ratio of the linear attenuation coefficient of the absorber to unit density. This parameter is important to use in the calculation of many photon interaction parameters [19]. The relationship between the linear attenuation coefficient and the mass attenuation coefficient is also given as follows:

$$
\mu_{m}=\mu \frac{1}{\rho}
$$

where $\rho$ is the density of the material $\left(\mathrm{g} / \mathrm{cm}^{3}\right)$. There are three terminologies generally used in the effectiveness of radiation shielding known as Half Value Layer HVL, Tenth Value Layer TVL and Mean Free Path MFP. HVL $(\mathrm{cm})$ is the thickness of a shield or an absorber at which the transmitted intensity is one half the initial intensity [20]. HVL is related to the linear attenuation coefficient value and is determined by the next equation [21]:

$$
H V L=\frac{\ln 2}{\mu} \simeq \frac{9.693}{\mu} .
$$

Moreover, Mean Free Path MFP (cm) is described as the average distance between two successive collisions of gamma-ray. It is expressed by the equation as follows [22]:

$$
M F P=\frac{1}{\mu} .
$$

The effectiveness of gamma-rays shielding is also described in term of the Tenth Value Layer TVL of the material. TVL $(\mathrm{cm})$ can be defined as the thickness of a shield or an absorber that would attenuate a radiation beam to $10 \%$ of its radiation level and is obtained using following equation [23]:

$$
T V L=\frac{\ln 10}{\mu} \simeq \frac{2.303}{\mu} .
$$

\section{RESULTS AND ANALYSIS}

In this study, the linear attenuation coefficient, the mass attenuation coefficient, Half Value Layer, Tenth Value Layer and Mean Free Path of the four shielding materials such as such as aluminium, iron, zirconium and tungsten have been calculated at various radioactive sources. Table 1 demonstrate the experimental values of the linear attenuation coefficient for four types of shielding material. It obtained by measuring the intensities of gamma-ray passed through the absorbers respectively. It is clear from the Table 1 , the linear attenuation coefficient values for tungsten has the highest value, and aluminum the lowest. The highest linear attenuation coefficient of tungsten material is due to its containment of high-atomic number and high-density that are more effective for gammaray attenuation. As seen from Table 1 and Fig.2, the values of the linear attenuation coefficient decreases with increasing incident energy. Therefore, the linear attenuation coefficient depend upon the energy of incident gamma. Then, the experimental linear attenuation coefficient values are compared the theoretical linear attenuation values [24-26]. It is clear Table 1 and Fig. 2 there is a good agreement between the experimental and theoretical values of the linear attenuation coefficient.

Another parameter measured in this word for the gamma-ray interactions is mass attenuation coefficient. The values of the mass attenuation coefficient of the four shielding materials measured by using equation (3). The experimental mass attenuation coefficient of the shielding materials at the mentioned radioactive sources have been shown in Table 2 . From the Table 2, it can be seen that tungsten also has higher value of the mass attenuation coefficient over all the gamma sources compared with other shielding materials due to its high atomic number and high density. Moreover, the experimental and theoretical values of mass attenuation coefficient are in a good agreement [24-26]. 
Table 1. Values of the experimental and theoretical linear attenuation coefficient $\mu\left(\mathrm{cm}^{-1}\right)$ for four types shielding material

\begin{tabular}{|c|c|c|c|c|c|c|c|c|c|}
\hline Nuclides & $\begin{array}{c}\text { Energy } \\
\text { (keV) }\end{array}$ & $\begin{array}{c}\text { Aluminium } \\
\text { Exp. }\end{array}$ & Theory & $\begin{array}{c}\text { Iron } \\
\text { Exp. }\end{array}$ & Theory & $\begin{array}{c}\text { Zirconium } \\
\text { Exp. }\end{array}$ & Theory & $\begin{array}{c}\text { Tungsten } \\
\text { Exp. }\end{array}$ & Theory \\
\hline Eu-152 & 244.67 & $3.61 \mathrm{E}-01$ & $3.35 \mathrm{E}-01$ & $1.14 \mathrm{E}+00$ & $1.15 \mathrm{E}+00$ & $1.46 \mathrm{E}+00$ & $1.46 \mathrm{E}+00$ & $1.11 \mathrm{E}+01$ & $1.51 \mathrm{E}+01$ \\
& 344.30 & $3.01 \mathrm{E}-01$ & $2.86 \mathrm{E}-01$ & $9.11 \mathrm{E}-01$ & $8.65 \mathrm{E}-01$ & $9.93 \mathrm{E}-01$ & $8.59 \mathrm{E}-01$ & $5.03 \mathrm{E}+00$ & $6.25 \mathrm{E}+00$ \\
Na-22 & 511.00 & $2.29 \mathrm{E}-01$ & $2.31 \mathrm{E}-01$ & $5.74 \mathrm{E}-01$ & $6.63 \mathrm{E}-01$ & $5.13 \mathrm{E}-01$ & $5.67 \mathrm{E}-01$ & $2.40 \mathrm{E}+00$ & $2.66 \mathrm{E}+00$ \\
Cs-137 & 661.00 & $1.92 \mathrm{E}-01$ & $2.00 \mathrm{E}-01$ & $4.89 \mathrm{E}-01$ & $5.78 \mathrm{E}-01$ & $4.21 \mathrm{E}-01$ & $5.06 \mathrm{E}-01$ & $1.61 \mathrm{E}+00$ & $2.11 \mathrm{E}+00$ \\
Eu-152 & 778.90 & $1.66 \mathrm{E}-01$ & $1.87 \mathrm{E}-01$ & $4.17 \mathrm{E}-01$ & $5.27 \mathrm{E}-01$ & $3.98 \mathrm{E}-01$ & $4.28 \mathrm{E}-01$ & $1.29 \mathrm{E}+00$ & $1.56 \mathrm{E}+00$ \\
Co-60 & 1171.00 & $1.39 \mathrm{E}-01$ & $1.48 \mathrm{E}-01$ & $3.91 \mathrm{E}-01$ & $4.79 \mathrm{E}-01$ & $2.99 \mathrm{E}-01$ & $3.36 \mathrm{E}-01$ & $9.93 \mathrm{E}-01$ & $1.08 \mathrm{E}+00$ \\
& 1333.00 & $1.35 \mathrm{E}-01$ & $1.37 \mathrm{E}-01$ & $3.86 \mathrm{E}-01$ & $3.84 \mathrm{E}-01$ & $2.81 \mathrm{E}-01$ & $3.06 \mathrm{E}-01$ & $7.42 \mathrm{E}-01$ & $9.65 \mathrm{E}-01$ \\
\hline
\end{tabular}
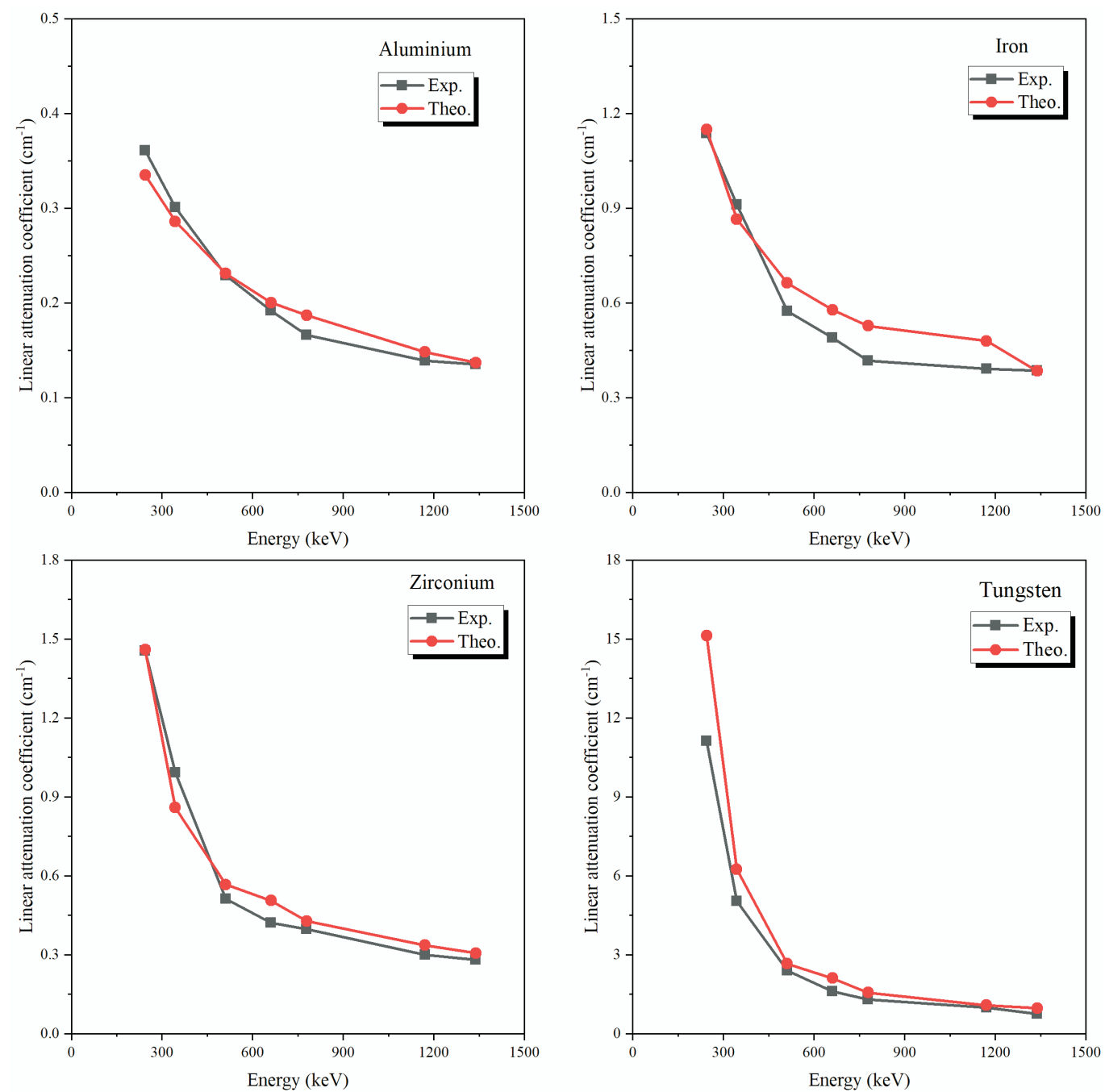

Fig.2. The graph of linear attenuation coefficient against photon energy for four types shielding material

The variation of the mass attenuation coefficient with incident energy of the four shielding materials are represented by Fig.3. From Fig.3, it is clearly shown that gamma ray mass attenuation coefficient also relies on the incident energy. Therefore, the mass attenuation coefficient also decreases with increasing incident energy. Half Value Layer, Tenth Value Layer and Mean Free Path are also there important parameters in designing any radiation shielding. HVL, TVL, and MFP of the shielding materials are given in Fig.4.
It can be seen that the aluminuim has the highest value of HVL, TVL, and MFP. While, Tungsten has the lowest value of the parameters. The lower HVL, TVL and MFP values of any shielding material is the better shielding performance. All parameters are nearly similar for the iron compared to zirconium. Although each of them has a different density, where ordinary iron shielding showed very poor results. Fig.4 also shows that HVL, TVL, and MFP are seen to increase with increasing the incident energy, as expected based on the mass attenuation coefficient. 
Table 2. Values of the experimental and theoretical linear attenuation coefficient $\mu\left(\mathrm{cm}^{-1}\right)$ for four types shielding material

\begin{tabular}{|c|c|c|c|c|c|c|c|c|c|}
\hline Nuclides & $\begin{array}{c}\text { Energy } \\
(\mathrm{keV})\end{array}$ & $\begin{array}{l}\text { Aluminium } \\
\text { Exp. }\end{array}$ & Theory & $\begin{array}{l}\text { Iron } \\
\text { Exp. }\end{array}$ & Theory & $\begin{array}{l}\text { Zirconium } \\
\text { Exp. }\end{array}$ & Theory & $\begin{array}{c}\text { Tungsten } \\
\text { Exp. }\end{array}$ & Theory \\
\hline \multirow[t]{2}{*}{ Eu-152 } & 244.67 & $1.32 \mathrm{E}-01$ & $1.22 \mathrm{E}-01$ & $1.44 \mathrm{E}-01$ & $1.46 \mathrm{E}-01$ & $2.23 \mathrm{E}-01$ & $2.24 \mathrm{E}-01$ & $5.76 \mathrm{E}-01$ & $7.84 \mathrm{E}-01$ \\
\hline & 344.30 & $1.10 \mathrm{E}-01$ & $1.04 \mathrm{E}-01$ & $1.16 \mathrm{E}-01$ & $1.10 \mathrm{E}$ & $1.52 \mathrm{E}-01$ & $1.32 \mathrm{E}-01$ & 2.61E-01 & $3.24 \mathrm{E}-01$ \\
\hline $\mathrm{Na}-22$ & 511.00 & $8.36 \mathrm{E}-02$ & $8.43 \mathrm{E}-02$ & $7.29 \mathrm{E}-02$ & 8.42 & 7.87E-02 & 8.70 & $1.24 \mathrm{~F}$ & $1.38 \mathrm{E}-01$ \\
\hline Cs-137 & 661.00 & 7.01E-02 & 7.31E-02 & $6.21 \mathrm{E}-02$ & $7.34 \mathrm{E}-02$ & $6.46 \mathrm{E}-02$ & $7.76 \mathrm{E}-02$ & $8.35 \mathrm{E}-02$ & $1.09 \mathrm{E}-01$ \\
\hline Eu-152 & 778.90 & $6.06 \mathrm{E}-02$ & $6.82 \mathrm{E}-02$ & $5.30 \mathrm{E}-02$ & & $6.10 \mathrm{E}-02$ & $6.56 \mathrm{E}-02$ & 6.69E-02 & 8.07E-02 \\
\hline \multirow[t]{2}{*}{ Co-60 } & 1171.00 & $5.07 \mathrm{E}-02$ & $5.40 \mathrm{E}-02$ & $4.97 \mathrm{E}-02$ & $6.08 \mathrm{E}-02$ & $4.59 \mathrm{E}-02$ & $5.15 \mathrm{E}-02$ & $5.15 \mathrm{E}-02$ & $5.58 \mathrm{E}-02$ \\
\hline & 1333.00 & 4.93E-02 & $5.00 \mathrm{E}-02$ & $4.90 \mathrm{E}-02$ & $4.88 \mathrm{E}-02$ & $4.31 \mathrm{E}-02$ & 4.69E-02 & $3.84 \mathrm{E}-02$ & $5.00 \mathrm{E}-02$ \\
\hline
\end{tabular}
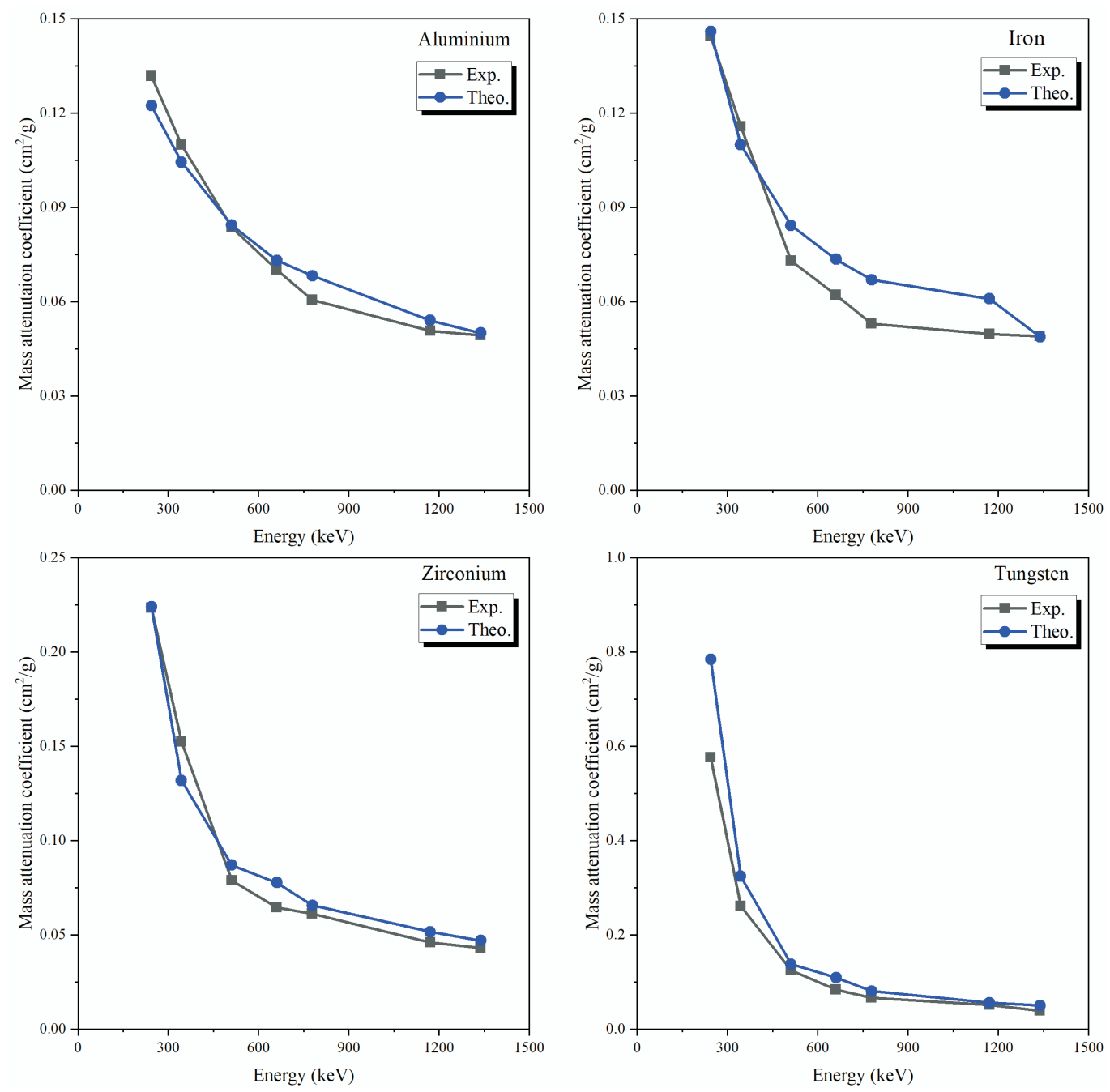

Fig.3. The graph of mass attenuation coefficient against photon energy for four types shielding material

\section{CONCLUSIONS}

In the present investigation, the attenuation properties of four types of shielding materials have been evaluated and discussed in terms of attenuation coefficient. The values of the linear attenuation coefficient and the mass attenuation coefficient decrease with increasing incident energy.

Therefore, tungsten appears as a good shielding material due to its higher value of atomic number and density. Therefore, Tungsten has the highest values of the linear attenuation coefficient and the mass attenuation coefficient compared to other shielding materials. The experimental results quite agreed with the theoretical values. The values of Half Value Layer HVL, Tenth Value Layer TVL, and Mean Free Path MFP were also determine for each materials. Aluminium absorber has the highest value of the above parameters and tungsten absorber has the lowest value. The lower HVL, TVL, and MFP values of any shielding material is the better shielding performance. 

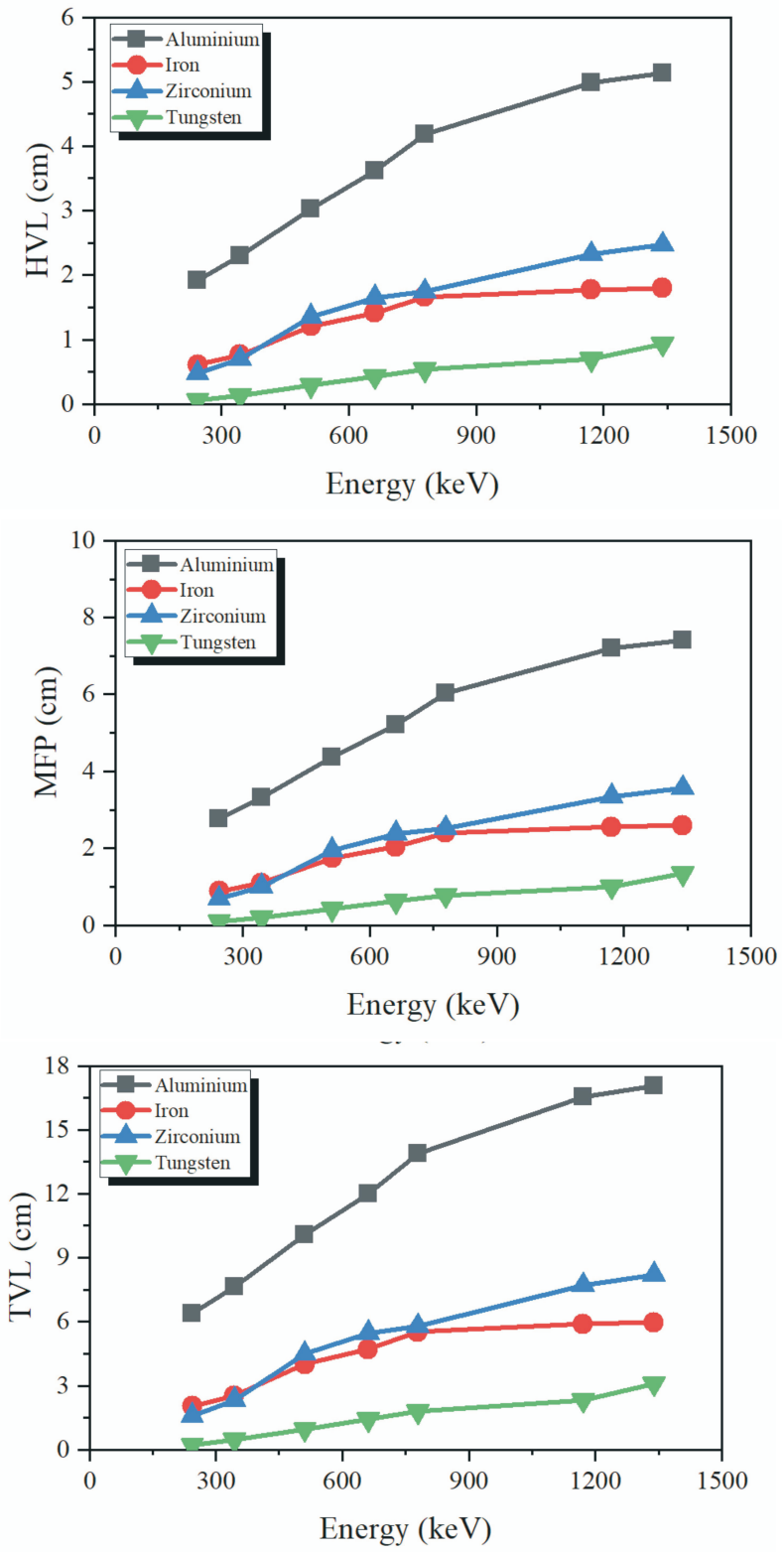

Fig.4. Variation of HVL, MFP and TVL for four types shielding material

\section{References}

1. M. Tunc, Ü. Çamdali, C. Parmaksizoğlu. Comparison of Turkey's electrical energy consumption and production with some European countries and optimization of future electrical power supply investments in Turkey // Energy Policy. 2006, v.34 (1), p.50-59.

2. A. Böke. Linear attenuation coefficients of tissues from $1 \mathrm{keV}$ to $150 \mathrm{keV} / /$ Radiation Physics and Chemistry. 2014, v.102, p.49-59.

3. R.M. Souza, R. Costa-Felix, A.V. Alvarenga. Attenuation Coefficient Variation as a Function of Temperature in a Cortical Bone Phantom // XXVI Brazilian Congress on Biomedical Engineering. Springer, 2019, p.807-810.
4. D. Wang, C. Li, S.J. Parikh, K.M. Scow. Impact of biochar on water retention of two agricultural soils-A multi-scale analysis // Geoderma. 2019, v.340, p.185-191.

5. M.W. Marashdeh, H. Saleh. Mass attenuation coefficient of olive peat material for absorbing gamma ray energy // Nuclear Science and Techniques. 2019, v.30(7), p.106.

6. R. Biswas, H. Sahadath, A.S. Mollah, M.F.Huq. Calculation of gamma-ray attenuation parameters for locally developed shielding material: Polyboron // Journal of Radiation Research and Applied Sciences. 2016, v.9(1), p.26-34.

7. R. Singh, S. Singh, G. Singh, K.S. Thind. Gamma radiation shielding properties of steel and iron slags // New J. of Glass and Ceramics. 2017, v.7, p.1-11.

8. A.M. Hamad, H.M. Qadr. Gamma-Rays Spectroscopy by Using a Thallium Activated Sodium Iodide $\mathrm{NaI}(\mathrm{Ti}) / /$ Eurasian Journal of Science $\ell$ Engineering. 2018, v.4(1), p.99-111.

9. O. Agar, H.O. Tekin, M. Sayyed, M.E. Korkmaz, O. Culfa, C. Ertugay. Experimental investigation of photon attenuation behaviors for concretes including natural perlite mineral // Results in Physics. 2019, v.12, p.237-243.

10. E.-S.A.Waly, M.A. Fusco, M.A. Bourham. Gamma-ray mass attenuation coefficient and half value layer factor of some oxide glass shielding materials // Annals of Nuclear Energy. 2016, v.96, p.26-30.

11. A.S. Ouda, H.A. Abdel-Gawwad. The effect of replacing sand by iron slag on physical, mechanical and radiological properties of cement mortar // HBRC Journal. 2017, v.13(3), p.255-261.

12. A.S. Ouda, H.S. Abdelgader. Assessing the physical, mechanical properties, and $\gamma$-ray attenuation of heavy density concrete for radiation shielding purposes // Geosystem Engineering. 2019, v.22(2), p.72-80.

13. E. Adamides, A. Kavadjiklis, S. Koutroubas, P.Koutroubas, N. Moshonas. New method for the determination of the linear attenuation coefficient of $\gamma$ rays in matter // AIP Conference Proceedings. AIP Publishing, 2019, p.200007.

14. A.H. Taqi, H.J. Khalil. Experimental and theoretical investigation of gamma attenuation of building materials // Journal of Nuclear and Particle Physics. 2017, v.7(1), p.6-13.

15. V.Singh, N. Badiger, S. Kothan, S. Kaewjaeng, T. Korkut, H. Kim, J. Kaewkhao. Gamma-ray and neutron shielding efficiency of $\mathrm{Pb}$-free gadolinium-based glasses // Nuclear Science and Techniques. 2016, v.27(4), p.103. 
16. O. Kilicoglu, H.O. Tekin, V.P. Singh. Determination of Mass Attenuation Coefficients of Different Types of Concretes using Monte Carlo Method // European Journal of Science and Technology. 2019, v.(15), p.591-598.

17. Z. Caner, M.Ç Tufan. Investigation of attenuation coefficients of some stainless steel and aluminum alloys // AIP Conference Proceedings, AIP Publishing, 2018, p.180002.

18. C. Celiktas. A method to determine the gammaray linear attenuation coefficient // Annals of Nuclear Energy. 2011, v.38(9), p.2096-2100.

19. F. Akman, M. Kacal, M. Sayyed, H. Karata. Study of gamma-radiation attenuation properties of some selected ternary alloys // Journal of Alloys and Compounds. 2019, v.782, p.315-322.

20. I. Akkurt, C. Basyigit, A. Akkas, Kilingarslan, B. Mavi, K. Giinoglu. Determination of some heavyweight aggregate half value layer thickness used for radiation shielding // Acta Physica Polonica-Series A General Physics. 2012, v.121(1), p.138.

21. M. Haque, M.Shamsuzzaman, M.B. Uddin, A.Z.M. Salahuddin, R.A.Khan. Fabrication and Characterization of Shielding Properties of Heavy Mineral Reinforced Polymer Composite Materials for Radiation Protection // European
Journal of Engineering Research and Science. 2019, v.4(3), p.15-20.

22. H.M. Qadr. Calculation for gamma ray buildup factor for aluminium, graphite and lead // International Journal of Nuclear Energy Science and Technology. 2019, v.13(1), p.61-69.

23. L. Seenappa, H. Manjunatha, B. Chandrika, H. Chikka. A study of shielding properties of $\mathrm{X}$-ray and gamma in barium compounds // Journal of Radiation Protection and Research. 2017, v.42(1), p.26-32.

24. J. Hubbell. Photon Cross Sections, Attenuation Coefficients and Energy Absorption Coefficients // National Bureau of Standards Report NSRDSNBS29, Washington DC, 1969.

25. J.H. Hubbell, S.M. Seltzer. Tables of X-ray mass attenuation coefficients and mass energyabsorption coefficients $1 \mathrm{keV}$ to $20 \mathrm{MeV}$ for elements $\mathrm{Z}=1$ to 92 and 48 additional substances of dosimetric interest // National Inst. of Standards and Technology-PL, Gaithersburg, MD (United), 1995.

26. M.J. Berger, J.Hubbell. XCOM: Photon cross sections on a personal computer // National Bureau of Standards, Washington, DC (USA). Center for Radiation. 1987.

\section{РАСЧЕТЫ ПАРАМЕТРОВ ПОГЛОЩЕНИЯ ГАММА-ИЗЛУЧЕНИЯ ДЛЯ АЛЮМИНИЯ, ЖЕЛЕЗА, ЦИРКОНИЯ И ВОЛЬФРАМА}

\section{Hiwa Mohammad Qadr}

Целью работы было определение коэффициента линейного поглощения, коэффициента полного поглощения, длины поглощения, длины десятикратного ослабления и среднего свободного пробега для разных материалов защиты, таких как: алюминий, железо, цирконий и вольфрам. Использовались энергии гамма-излучений от источников: ${ }^{152} \mathrm{Eu},{ }^{22} \mathrm{Na},{ }^{137} \mathrm{Cs}$ и ${ }^{60} \mathrm{Co}$. Для достижения цели измерения параметров поглощения были выполнены с использованием $N a I(T I)$-детектора. Проведено сравнение вычисленных величин всех параметров данных материалов защиты. Результаты полученных параметров показывают, что вольфрам является лучшим в сравнении с другими материалами защиты. Затем эти параметры были сравнены с теоретическими значениями.

\section{РОЗРАХУНКИ ПАРАМЕТРІВ ПОГЛИНАННЯ ГАММА-ВИПРОМІНЮВАННЯ ДЛЯ АЛЮМІНІЮ, ЗАЛІЗА, ЦИРКОНІЮ ТА ВОЛЬФРАМУ}

\section{Hiwa Mohammad Qadr}

Метою работи було визначення коефіцієнта лінійного поглинання, коефіцієнта повного поглинання, довжини поглинання, довжини десятикратного ослаблення і среднього вільного пробігу для різних матеріалів захисту, таких як: алюміній, залізо, цирконій та вольфрам. Використовувались енергії гаммавипромінювань від джерел: ${ }^{152} \mathrm{Eu},{ }^{22} \mathrm{Na},{ }^{137} \mathrm{Cs}$ і ${ }^{60} \mathrm{Co}$. Для досягнення цілі вимірювання параметрів поглинання були виконані із застосуванням $N a I(T I)$-детектора. Проведено порівняння отриманих величин всіх параметрів даних матеріалів захисту. Результати отриманих параметрів показують, що вольфрам є кращим у порівнянні з іншими матеріалами захисту. I, нарешті, отримані параметри були порівняні з теоретичними величинами. 